\title{
Brucella, a Monospecific Genus as Shown by Deoxyribonucleic Acid Hybridization
}

\author{
JEAN-MICHEL VERGER, ${ }^{1 *}$ FRANCINE GRIMONT, ${ }^{2}$ PATRICK A. D. GRIMONT, ${ }^{2}$ AND MAGGY GRAYON ${ }^{1}$ \\ Station de Pathologie de la Reproduction, Centre de Recherches de Tours, Institut National de la Recherche \\ Agronomique, Nouzilly, F-37380 Monnaie, France, ${ }^{1}$ and Unité des Entérobactéries, Institut National de la Santé et de la \\ Recherche Médicale Unité 199, Institut Pasteur, F-75724 Paris Cedex 15, France ${ }^{2}$
}

\begin{abstract}
A total of 51 strains (including type, reference, vaccine, and field strains) representing all species and biovars of Brucella formed a single deoxyribonucleic acid-deoxyribonucleic acid hybridization group (S1 nuclease method). Accordingly, we propose that only one species, Brucella melitensis, be recognized in the genus. We recommend that other specific epithets formerly associated with the generic name Brucella be used in a vernacular form for biovar designation (e.g., Brucella melitensis biovar Abortus 1).
\end{abstract}

At present, the genus Brucella Meyer and Shaw 1920 contains six species, Brucella melitensis (Hughes 1893) Meyer and Shaw 1920, Brucella abortus (Schmidt 1901) Meyer and Shaw 1920, Brucella suis Huddleson 1929, Brucella ovis Buddle 1956, Brucella neotomae Stoenner and Lackman 1957, and Brucella canis Carmichael and Bruner $1968(8,20)$. These species were proposed on the basis of differential tests and different preferential hosts (8).

The identification of these bacteria at the species level is difficult and best suited to reference laboratories.

In 1968, Hoyer and McCullough $(13,14)$ studied six strains of Brucella, one of each species, by deoxyribonucleic acid (DNA)-DNA hybridization, using the DNA-agar method and a filter method. These authors $(13,14)$ found that their strains are highly related. Unfortunately, the work of Hoyer and McCullough $(13,14)$ had a limited impact on the taxonomy of the genus Brucella, probably because DNA hybridization technology and its interpretation had not reached the state of development which it now has, too few strains were studied, and only two of the strains were type strains (B. melitensis $16 \mathrm{M}$ and B. canis RM6/66).

The purpose of the present study was to apply modern DNA-DNA hybridization methods to 51 strains (including type strains) representing all present species and biovars of Brucella. Our results give no support to the division of the genus Brucella into more than one species. Consequently, we propose that only one species, $B$. melitensis, be recognized in this genus.

\section{MATERIALS AND METHODS}

Bacterial strains. The 51 strains used in this study are listed in Table 1. All strains were kept freeze-dried in the Brucella Culture Collection, INRA-Nouzilly, Monnaie, France. Cultures were grown on Trypcase Soy Agar (Bio-Mérieux, Marcy l'Etoile, France) supplemented with $0.1 \%$ (wt/vol) yeast extract (Difco Laboratories, Detroit, Mich.) (TSAYE medium). For fastidious strains (B. abortus biovar 2 and African biovar 3 and $B$. ovis), sterile equine serum (BioMérieux) was added to TSAYE medium to a final concentration of $5 \%(\mathrm{vol} / \mathrm{vol})(\mathrm{TSAYES}$ medium). The strains were checked for purity and species and biovar characterization by using standard procedures (1).

DNA preparation. For each strain, six Roux flasks containing $250 \mathrm{ml}$ of TSAYE or TSAYES medium were inoculated

\footnotetext{
* Corresponding author.
}

with a 5-ml suspension in saline ( $\mathrm{pH}$ 6.8) made with a 1-day culture on TSAYE or TSAYES medium slopes. After incubation for $72 \mathrm{~h}$ at $37^{\circ} \mathrm{C}$ under air (supplemented with $10 \%$ [vol/vol] $\mathrm{CO}_{2}$ if required), the growth from the six Roux flasks was harvested with $120 \mathrm{ml}$ of $0.05 \mathrm{M}$ tris(hydroxymethyl)- aminomethane-0.05 $\mathrm{M}$ ethylenediaminetetraacetic acid-0.1 M NaCl buffer ( $\mathrm{pH} 8)$. This suspension was checked for purity by streaking onto TSAYE or TSAYES medium. Then $2.6 \mathrm{ml}$ of a $25 \%$ (wt/vol) aqueous solution of sodium dodecyl sulfate (BDH, Poole, England) and $0.4 \mathrm{ml}$ of a $2 \%$ (wt/vol) pronase (Sigma Chemical Co., St. Louis, Mo.) solution were added. The mixture was vigorously shaken and then incubated with slight rotary shaking (120 cycles per min) overnight at $37^{\circ} \mathrm{C}$ to maximize cell lysis. The sodium dodecyl sulfate mixture was then placed in a water bath at $60^{\circ} \mathrm{C}$ for $1 \mathrm{~h}$ to kill the surviving Brucella cells.

DNA was extracted and purified from the cell lysate by using previously described procedures (4). Samples of DNA preparations were sheared by sonication (4). Sheared DNAs were dialyzed overnight against $0.042 \mathrm{M} \mathrm{NaCl}$ and stored at $4^{\circ} \mathrm{C}$ over a layer of chloroform.

DNA-DNA hybridization. Native DNA was labeled in vitro by nick translation (12). The $S 1$ nuclease method (9) was used; we used a procedure ( $\mathrm{S} 1$ nuclease-trichloroacetic acid) described elsewhere (12), except that all volumes were reduced by one-half. Labeled DNA (about $10 \mathrm{ng}$ ) and unlabeled DNA $(75 \mu \mathrm{g})$ were heat denatured, adjusted to $0.42 \mathrm{M} \mathrm{NaCl}$ (final volume, $0.5 \mathrm{ml}$ ), and incubated at $60^{\circ} \mathrm{C}$ for $16 \mathrm{~h}$.

The temperature $\left(T_{m}\right)$ at which $50 \%$ of the reassociated DNA became hydrolyzable by the $S 1$ nuclease was determined (9). The difference $\left(\Delta T_{m}\right)$ between the $T_{m}$ of the homologous reaction (homoduplex) and the $T_{m}$ of the heterologous reaction (heteroduplex) is an estimate of the divergence between two DNAs (2).

\section{RESULTS}

The DNA relatedness results obtained with labeled reference DNA from B. melitensis strain $16 \mathrm{M}^{\mathrm{T}}\left(=\right.$ ATCC $23456^{\mathrm{T}}$ $[\mathrm{T}=$ type strain]) and unlabeled DNAs from 50 other Brucella strains are shown in Table 1 . The 50 strains formed a homogeneous DNA relatedness group that was $96 \pm 5 \%$ (mean \pm standard deviation) related to strain $16 \mathrm{M}^{\mathrm{T}}$, with $\Delta T_{m}$ values below $1^{\circ} \mathrm{C}$.

Reciprocal DNA relatedness data for the type strains of the six conventional Brucella species are shown in Table 2. 
TABLE 1. Reassociation of labeled DNA from B. melitensis $16 \mathrm{M}^{\mathrm{T}}$ with DNAs of Brucella strains representing all species and biovars presently recognized within the genus Brucella ${ }^{a}$

\begin{tabular}{|c|c|c|c|c|c|}
\hline \multicolumn{5}{|c|}{ Source of unlabeled DNA } & \multirow[b]{2}{*}{$\begin{array}{l}\text { Relative binding } \\
\text { ratio }(\%) \text { at } 60^{\circ} \mathrm{C}\end{array}$} \\
\hline Species & $\begin{array}{l}\text { Species Biovar } \\
\text { or type of } \\
\text { isolate }\end{array}$ & Strain $^{b}$ & Host or source & $\begin{array}{l}\text { Geographic } \\
\text { origin }\end{array}$ & \\
\hline \multirow[t]{13}{*}{ B. melitensis } & Biovar 1 & $16 \mathrm{M}^{\mathrm{T}}\left(=\mathrm{BCCN} \mathrm{R} 1^{\mathrm{T}}=\overline{\left.\text { ATCC } 23456^{\mathrm{T}}\right)}\right.$ & Goat & United States & $100(0.0)^{r}$ \\
\hline & & BCCN 83225 & Human & France & 102 \\
\hline & & $\mathrm{H} 38(=\mathrm{BCCN}$ V3) & Human & Mexico & 103 \\
\hline & & Revl (= BCCN V4a) & Goat & Mexico & 104 \\
\hline & & $\operatorname{Revl}(=\mathrm{BCCN}$ V4b) & Goat & Mexico & 107 \\
\hline & & $\operatorname{Revl}(=\mathrm{BCCN} V 4 \mathrm{c})$ & Goat & Mexico & 101 \\
\hline & & $\operatorname{Revl}(=\mathrm{BCCN}$ V4d) & Goat & Mexico & 103 \\
\hline & Biovar 2 & $63 / 9(=\mathrm{BCCN}$ R2 $=$ ATCC 23457) & Goat & Turkey & 93 \\
\hline & & BCCN 82.59 & Human & Spain & 93 \\
\hline & & BCCN 84.3 & Dog & Costa Rica & $93(0.6)$ \\
\hline & Biovar 3 & Ether $(=$ BCCN R3 $=$ ATCC 23458) & Goat & Italy & 91 \\
\hline & & BCCN 82.11 & Sheep & France & $92(0.7)$ \\
\hline & Rough isolate & BCCN R19 & Goat & Malta & 95 \\
\hline \multirow{23}{*}{ B. abortus } & Biovar 1 & $544^{\mathrm{T}}\left(=\mathrm{BCCN} \mathrm{R} 4^{\mathrm{T}}=\operatorname{ATCC} 23448^{\mathrm{T}}\right)$ & Cattle & England & $87(0.7)$ \\
\hline & & BCCN 83.29 & Cattle & France & 91 \\
\hline & & 544. $\mathrm{CO}_{2}$ independent $\left(=\mathrm{BCCN} \mathrm{R4} \mathrm{CO}_{2}^{-}\right)$ & $\begin{array}{l}\text { Laboratory variant } \\
\text { of strain } 544^{\mathrm{T}}\end{array}$ & & 87 \\
\hline & & $\mathrm{B} 19(=\mathrm{BCCN}$ V1) & Cattle & United States & 103 \\
\hline & Biovar 2 & $86 / 8 / 59(=$ BCCN R5 $=$ ATCC 23449) & Cattle & England & 94 \\
\hline & & BCCN 83.86 & Cattle & France & 94 \\
\hline & & BCCN 78.7 & Human & France & 91 \\
\hline & Biovar 3 & Tulya $(=$ BCCN R6 = ATCC 23450) & Human & Uganda & 90 \\
\hline & & BCCN 83.74 & Cattle & France & 101 \\
\hline & & BCCN 83.20 & Cattle & Niger & 97 \\
\hline & & BCCN 76.166 & Cattle & Senegal & $93(+0.8)$ \\
\hline & & BCCN 83.31 & Cattle & Rwanda & 92 \\
\hline & & BCCN 80.204 & Cattle & Togo & 94 \\
\hline & & BCCN 77.79 & Human & France & 92 \\
\hline & Biovar 4 & $292(=\mathrm{BCCN} \mathrm{R7}=\mathrm{ATCC} 23451)$ & Cattle & England & 100 \\
\hline & & BCCN 80.190 & Cattle & France & 99 \\
\hline & Biovar 5 & B3196 ( = BCCN R8 $=$ ATCC 23452) & Cattle & England & 94 \\
\hline & & BCCN $84.16(=$ CVL 201/78) & Cattle & Scotland & 96 \\
\hline & Biovar 6 & $870(=$ BCCN R9 $=$ ATCC 23453$)$ & Cattle & Africa & 98 \\
\hline & & BCCN 80.238 & Human & France & 98 \\
\hline & Biovar 9 & C68 (= BCCN R11 = ATCC 23455) & Cattle & England & 94 \\
\hline & & BCCN 83.9 & Cattle & Belgium & 93 \\
\hline & Rough isolate & $45 / 20(=\mathrm{BCCN} V 2)$ & Cattle & England & 96 \\
\hline \multirow[t]{9}{*}{ B. suis } & Biovar 1 & $1330^{\mathrm{T}}\left(=\right.$ BCCN R12 $\left.{ }^{\mathrm{T}}=\operatorname{ATCC} 23444^{\mathrm{T}}\right)$ & Swine & United States & $105(0.9)$ \\
\hline & & $\mathrm{BCCN} 78.157$ & Human & France & 102 \\
\hline & Biovar 2 & Thomsen $(=$ BCCN R13 = ATCC 23445) & Swine & Denmark & 96 \\
\hline & & BCCN 82.4 & Hare & France & $101(0.4)$ \\
\hline & Biovar 3 & $686(=$ BCCN R14 = ATCC 23446) & Swine & United States & 97 \\
\hline & & BCCN 83.210 & Wild rodent & Australia & 85 \\
\hline & Biovar 4 & $40(=\mathrm{BCCN} \mathrm{R} 15=\mathrm{ATCC} 23447)$ & Reindeer & USSR & 94 \\
\hline & & BCCN RT1 & Caribou & Alaska & 84 \\
\hline & Biovar 5 & BCCN 82.75 (= CVL ELT80) & Human & England & 93 \\
\hline \multirow{2}{*}{ B. neotomae } & & $5 \mathrm{~K}^{2} 3^{\mathrm{T}}\left(=\mathrm{BCCN} \mathrm{R} 16^{\mathrm{T}}=\right.$ ATCC $\left.23459^{\mathrm{T}}\right)$ & Desert wood rat & United States & $99(0.5)$ \\
\hline & & $\mathrm{BCCN} N 1$ & Desert wood rat & United States & $92(0.0)$ \\
\hline \multirow[t]{2}{*}{ B. ovis } & & $63 / 290^{\mathrm{T}}\left(=\mathrm{BCCN} \mathrm{R} 17^{\mathrm{T}}=\operatorname{ATCC} 25840^{\mathrm{T}}\right)$ & Sheep & Africa & $92(0.5)$ \\
\hline & & BCCN O1 & Sheep & France & $98(+1.5)$ \\
\hline \multirow[t]{2}{*}{ B. canis } & & $\underset{\left.23365^{\mathrm{T}}\right)}{\mathrm{RM6} / 66^{\mathrm{T}}}\left(=\mathrm{BCCN} \mathrm{R} 18^{\mathrm{T}}=\mathrm{ATCC}\right.$ & Dog & United States & $99(0.9)$ \\
\hline & & BCCN C1 $(=\operatorname{CIP} 74.36)$ & Dog & Madagascar & $91(0.5)$ \\
\hline
\end{tabular}

${ }^{a}$ B. abortus biovar 7 was discarded from this study, as Food and Agriculture Organization/World Health Organization reference strain $63 / 75(=$ ATCC 23454$)$ is not a pure culture and no authentic isolate has been reported for many years. In 1978 B. abortus biovar 8 was deleted by the Subcommittee on Taxonomy of $B r u-$ cella from the list of biovars as no authentic isolate of this biovar had been reported for many years and no reference strain was available (6).

${ }^{b}$ ATCC, American Type Culture Collection, Rockville, Md.; BCCN, Brucella Culture Collection, Nouzilly, France; CIP, Collection of Pasteur Institute, Paris, France; CVL, Brucella Culture Collection, Central Veterinary Laboratory, Weybridge, England. Type strains and biovar reference strains are listed first by their Food and Agriculture Organization/World Health Organization designations and then by their BCCN and ATCC numbers. The reference strain of B. suis biovar 5 recently proposed by the Subcommittee on Taxonomy of Brucella (7) has not been chosen yet. Vaccine strains are listed first by their worldwide known designations (i.e., H38, Rev1, B19, and 45/20) and then by their BCCN numbers. Because of some differences in growth characteristics, antibiotic resistance, and protective activity, vaccine strain Rev1 originated from four different laboratories. Rev1 ( = BCCN V4a) is the original strain of S. S. Elberg; this strain is a nondependent reverse clone of a streptomycin-dependent mutant of a virulent $B$. melitensis strain (strain 6056 of $\mathrm{M}$. Ruiz-Castañeda, Mexico City, Mexico). Rev1 (= BCCN V4b) is the strain Rev1 used at the Centro Panamericano de Zoonosis, Buenos Aires, Argentina. Rev1 (= BCCN V4c) is the strain Rev1 used at the Veterinary Research Institute, Onderstepoort, South Africa. Rev1 (= BCCN V4d) is the strain Rev1 which has been maintained at Nouzilly, France, since 1970 and originated from Madison, Wis. Field strains are listed by their BCCN numbers and, for some, also by their CVL or CIP numbers.

c The numbers in parentheses are $\Delta T_{m}$ values (in degrees Celsius). 
TABLE 2. Levels of DNA relatedness among the type strains of the six conventional Brucella species

\begin{tabular}{|c|c|c|c|c|c|c|}
\hline \multirow{2}{*}{$\begin{array}{l}\text { Unlabeled DNA from } \\
\text { strain: }\end{array}$} & \multicolumn{6}{|c|}{ \% DNA relatedness with labeled DNA from strain: } \\
\hline & $\begin{array}{l}\text { B. melitensis } \\
16 \mathrm{M}^{\mathrm{T}}\end{array}$ & B. abortus & $\begin{array}{l}\text { B. suis } \\
1330^{\mathrm{I}}\end{array}$ & $\begin{array}{l}\text { B. neotomae } \\
5 \mathrm{~K} 33^{\mathrm{T}}\end{array}$ & $\begin{array}{l}\text { B. ovis } \\
63 / 290^{\mathrm{T}}\end{array}$ & $\begin{array}{l}\text { B. canis } \\
\text { RM6/66 }^{\mathrm{T}}\end{array}$ \\
\hline$\overline{B .}$ melitensis $16 \mathrm{M}^{\mathrm{T}}$ & 100 & 93 & 92 & 89 & 99 & 97 \\
\hline B. abortus $544^{\mathrm{T}}$ & 87 & 100 & 100 & 94 & 89 & 103 \\
\hline B. suis $1330^{\mathrm{T}}$ & 105 & 100 & 100 & 98 & 93 & 110 \\
\hline B. neotomae $5 \mathrm{~K} 33^{\mathrm{T}}$ & 99 & 104 & 102 & 100 & 103 & 99 \\
\hline B. ovis $63 / 290^{\mathrm{T}}$ & 92 & 94 & 100 & 90 & 100 & 110 \\
\hline
\end{tabular}

The level of relatedness among all species was more than $87 \%$.

\section{DISCUSSION}

The genus Brucella is not significantly related to Bordetella (14), Alcaligenes (14), Francisella (13), Haemophilus (21), Moraxella (21), or the Enterobacteriaceae (13, 14), as determined by DNA-DNA hybridization. As determined by DNA-ribosomal ribonucleic acid hybridization, the genus Brucella belongs to ribosomal ribonucleic acid superfamily IV (10), which contains Agrobacterium, Rhizobium, Mycoplana, Phylobacterium, and Centers for Disease Control group Vd (10).

The identification of the present nomenspecies of Brucella can be difficult, and intermediate strains are occasionally found. Tests for substrate oxidation, although reliable for identification (8), require the use of a Warburg apparatus (or thin-layer chromatography) and are limited to reference laboratories. Other biochemical tests $\left(\mathrm{CO}_{2}\right.$ requirement, $\mathrm{H}_{2} \mathrm{~S}$ production, susceptibility to dyes) do not allow safe identification of nomenspecies, but are necessary for biovar identification (8). Nonrough strains cross-react in agglutination tests with antisera, and antigenic differences among biovars are quantitative rather than qualitative. Tests of lysis by a battery of four to six phages allow identification of Brucella nomenspecies ( 8 ).

In the taxonomy of any other genus, species behaving like Brucella nomenspecies would be treated as biovars or phagovars. Controversy has occurred concerning the classification of some Brucella taxa. Rough strains of Brucella isolated from dogs were proposed either as a biovar of $B$. suis (17) or as a separate species, $B$. canis (5). The latter proposal has been followed by the Subcommittee on Taxonomy of Brucella (6), and the nature of the animal host weighed heavily in this decision. Brucella strains isolated from reindeer presently constitute biovar 4 of $B$. suis (6), although Russian authors currently use the species name "Brucella rangiferi" (18) for these strains. Thus, there have been no scientific criteria to delineate species. In fact, present Brucella nomenspecies are only groups of biovars. This conclusion was reached 27 years ago by Renoux (19).

The levels of homology among all Brucella "species" are very high despite the fact that the $\mathrm{S} 1$ nuclease method is known to give lower homology values than all other DNA hybridization methods $(12,15)$. The range of $\Delta T_{m}$ values is similar to that observed within a subspecies $(3,11)$. Clearly, the 51 strains which we studied belong to a single genomic species with no subdivision deducible from DNA data. Overall, our results confirm and extend those published 17 years ago by Hoyer and McCullough $(13,14)$. However, the 2 to $3 \%$ deletion in the genome of a $B$. ovis strain that Hoyer and McCullough $(13,14)$ deduced from their reciprocal experiments was not confirmed by our study. It should be recalled that the standard error of DNA relatedness results is currently about $3 \%$ (12).

We believe that taxonomy is a science and that nomenclature should be in accord with this science. Therefore, we propose that only one species, $B$. melitensis (Hughes 1893) Meyer and Shaw 1920, be recognized in the genus Brucella. $B$. abortus, B. suis, B. neotomae, $B$. ovis, and $B$. canis are thus subjective synonyms of $B$. melitensis (the type species). We suggest that specific epithets, other than the specific epithet of $B$. melitensis, formerly associated with the generic name Brucella be used in a vernacular form (i.e., not italicized) to refer to biovars (e.g., B. melitensis biovar Abortus 2). Infrasubspecific taxon designation is not regulated by the International Code of Nomenclature of Bacteria (16) and is the domain of the International Committee on Systematic Bacteriology Subcommittee on Taxonomy of Brucella.

The amended description of the single species in the genus Brucella, B. melitensis, is exactly that presently given for the genus Brucella (8). The type strain remains strain $16 \mathrm{M}$ (= ATCC 23456).

\section{ACKNOWLEDGMENT}

One of us (J.-M.V.) thanks L. Le Minor for hospitality in the Unite des Entérobactéries.

\section{LITERATURE CITED}

1. Alton, G. G., L. M. Jones, and D. E. Pietz. 1975. Laboratory techniques in brucellosis, 2nd ed. World Health Organization, Geneva

2. Bonner, T. I., D. J. Brenner, B. R. Neufeld, and R. J. Britten. 1973. Reduction in the rate of DNA reassociation by sequence divergence. J. Mol. Biol. 81:121-135.

3. Brenner, D. J. 1978. Characterization and clinical identification of Enterobacteriaceae by DNA hybridization. Prog. Clin. Pathol. 7:71-117.

4. Brenner, D. J., A. C. McWhorter, J. K. Leete Knutson, and A. G. Steigerwalt. 1982. Escherichia vulneris: a new species of Enterobacteriaceae associated with human wounds. J. Clin. Microbiol. 15:1133-1140.

5. Carmichael, L. E., and D. W. Bruner. 1968. Characteristics of a newly-recognized species of Brucella responsible for infectious canine abortion. Cornell Vet. 58:579-592.

6. Corbel, M. J. 1982. International Committee on Systematic Bacteriology Subcommittee on Taxonomy of Brucella. Minutes of Meeting, 4 and 5 September 1978. Int. J. Syst. Bacteriol. 32:260-261.

7. Corbel, M. J. 1984. International Committee on Systematic Bacteriology Subcommittee on Taxonomy of Brucella. Minutes of Meeting, 10 August 1982. Int. J. Syst. Bacteriol. 34:366-367.

8. Corbel, M. J., and W. J. Brinley-Morgan. 1984. Genus Brucella Meyer and Shaw $1920,173^{\mathrm{AL}}$, p. 377-388. In N. R. Krieg and J. C. Holt (ed.), Bergey's manual of systematic bacteriology, vol. 1. The Williams \& Wilkins Co., Baltimore. 
9. Crosa, J. H., D. J. Brenner, and S. Falkow. 1973. Use of a single-strand specific nuclease for analysis of bacterial and plasmid deoxyribonucleic acid homo- and heteroduplexes. J. Bacteriol. 115:904-911.

10. De Ley, J., W. Mannheim, P. Segers, K. Kersters, K. H. Hinz, and A. Lievens. 1983. Taxonomy of the genus Bordetella, p. 245-251. In H. Leclerc (ed.), Les bacilles à gram négatif d'intérêt médical et en santé publique: taxonomie, identification, applications. Institut National de la Santé et de la Recherche Médicale, Paris.

11. Grimont, P. A. D. 1984. DNA/DNA hybridization in bacterial taxonomy, p. 11-19. In A. Sanna and G. Morace (ed.), New horizons in microbiology. Elsevier, Amsterdam.

12. Grimont, P. A. D., M. Y. Popoff, F. Grimont, C. Coynault, and M. Lemelin. 1980. Reproductibility and correlation study of three deoxyribonucleic acid procedures. Curr. Microbiol. 4:325-330.

13. Hoyer, B. H., and N. B. McCullough. 1968. Polynucleotide homologies of Brucella deoxyribonucleic acids. J. Bacteriol. 95:444-448.

14. Hoyer, B. H., and N. B. McCullough. 1968. Homologies of deoxyribonucleic acids from Brucella ovis, canine abortion organisms, and other Brucella species. J. Bacteriol. 96: $1783-1790$.
15. Johnson, J. L. 1984. Nucleic acids in bacterial classification, p. 8-11. In N. R. Krieg and J. C. Holt (ed.), Bergey's manual of systematic bacteriology, vol. 1. The Williams \& Wilkins Co., Baltimore.

16. Lapage, S. P., P. H. A. Sneath, E. F. Lessel, V. B. D. Skerman, H. P. R. Seeliger, and W. A. Clark (ed.). 1975. International code of nomenclature of bacteria. 1975 Revision. American Society for Microbiology, Washington, D.C.

17. Meyer, M. E. 1969. Brucella organisms isolated from dogs: comparison of characteristics of members of the genus Brucella. Am. J. Vet. Res. 30:1751-1756.

18. Pinigin, A. F., O. S. Petukhova, and S. P. Merinov. 1983. Taxonomic status of Brucella strains from reindeer. $\mathrm{Zh}$. Mikrobiol. Epidemiol. Immunobiol. No. 11, p. 103-105. (In Russian.)

19. Renoux, G. 1958. La notion d'espèce dans le genre Brucella. Ann. Inst. Pasteur Paris 94:179-206.

20. Skerman, V. B. D., V. McGowan, and P. H. A. Sneath (ed.). 1980. Approved lists of bacterial names. Int. J. Syst. Bacteriol. 30:225-420.

21. Sugimoto, C., Y. Isayama, R. Sakazaki, and S. Kuramochi. 1983. Transfer of Haemophilus equigenitalis Taylor et al. 1978 to the genus Taylorella gen. nov. as Taylorella equigenitalis comb. nov. Curr. Microbiol. 9:155-162. 